\begin{tabular}{|l|l|l|}
\hline \multicolumn{2}{|c|}{ PublisherInfo } \\
\hline \hline PublisherName & $:$ & BioMed Central \\
\hline \hline PublisherLocation & $:$ & London \\
\hline \hline PublisherImprintName & $:$ & BioMed Central \\
\hline \hline
\end{tabular}

\title{
Muscling in on microarrays
}

\begin{tabular}{|l|l|l||}
\hline \multicolumn{2}{|c||}{ ArticleInfo } \\
\hline \hline ArticleID & $:$ & 4629 \\
\hline \hline ArticleDOI & $:$ & $10.1186 /$ gb-spotlight-20021107-01 \\
\hline \hline ArticleCitationID & $:$ & spotlight-20021107-01 \\
\hline \hline ArticleSequenceNumber & $:$ & 295 \\
\hline \hline ArticleCategory & $:$ & Research news \\
\hline ArticleFirstPage & $:$ & 1 \\
\hline \hline ArticleLastPage & $:$ & 2 \\
\hline \hline & & RegistrationDate : 2002-11-7 \\
\hline ArticleHistory & $:$ & OnlineDate \\
\hline \hline ArticleCopyright & $:$ & BioMed Central Ltd2002-11-7 \\
\hline \hline ArticleGrants & $:$ & \\
\hline \hline ArticleContext & $:$ & 130593311 \\
\hline \hline
\end{tabular}




\section{Jonathan B Weitzman}

Email: jonathanweitzman@hotmail.com

Duchenne muscular dystrophy (DMD) is a degenerative disease of the skeletal muscle fibres and is caused by mutations in the dystrophin gene. In the Early Edition of the Proceedings of the National Academy of Sciences, Haslett et al. report microarray analysis of muscle from DMD patient biopsies to gain insights into the molecular pathways affected in dystrophic skeletal muscle. Twelve quadriceps biopsies from DMD patients were compared with unaffected controls and the hybridization data were analysed using two different statistical methods ( $t$ test analysis and geometric fold-change analysis). Over one hundred genes were identified, many of which fit with the histopathology of the disease. For example, several components of the proliferating connective tissue were found to be overexpressed in DMD muscle.

\section{References}

1. Muscular dystrophy, Duchenne type; DMD, [http://www.ncbi.nlm.nih.gov/entrez/ dispomim.cgi?id=310200]

2. The structural and functional diversity of dystrophin.

3. Proceedings of the National Academy of Sciences, [http://www.pnas.org]

4. Gene expression comparison of biopsies from Duchenne muscular dystrophy (DMD) and normal skeletal muscle, [http://www.pnas.org/cgi/doi/10.1073/pnas.192571199] 